\title{
Adolescent Pregnancy and Delivery in the Rural Areas of DR. Congo: A Cross-Sectional Descriptive Study (2014 to 2016)
}

\author{
Bukasa Héman Kabemba1,2,3, Yuma Gaston Alimasi ${ }^{4}$, Augustin Mpo Ntambwe ${ }^{5}$, \\ Morega Esaïe Kalamba ${ }^{4}$, Faïlla Fanny Kitenge ${ }^{4}$, Olivier Ejiba Nyongonyi ${ }^{6}$, \\ Huguette Kisimba Monzi ${ }^{*}$
}

\begin{abstract}
${ }^{1}$ Department of Nursing, Higher Institute of Medical Techniques of Kalemie, Kalemie, Democratic Republic of Congo
${ }^{2}$ Department of Nursing Sciences, Faculty of Health Sciences, University Institute of Congo, Lubumbashi,

Democratic Republic of Congo

${ }^{3}$ Department of Nursing Sciences, Higher Institute of Medical Techniques of Tshofa, Tshofa, Democratic Republic of Congo

${ }^{4}$ Department of Public Health, Faculty of Medicine, University of Kalemie, Kalemie, Democratic Republic of Congo

${ }^{5}$ Department of Nursing Sciences, Higher Institute of Medical Techniques of Lubao, Lubao, Democratic Republic of Congo

${ }^{6}$ Department of Health Community and Nursing Sciences, Higher Institute of Medical Techniques of Kabinda, Kabinda,

Democratic Republic of Congo

${ }^{7}$ Department of Nursing, Higher Institute of Medical Techniques of Moba, Moba, Democratic Republic of Congo

Email: *hemanuska@gmail.com
\end{abstract}

How to cite this paper: Kabemba, B.H., Alimasi, Y.G., Ntambwe, A.M., Kalamba, M.E., Kitenge, F.F., Nyongonyi, O.E. and Monzi, H.K. (2018) Adolescent Pregnancy and Delivery in the Rural Areas of DR. Congo: A Cross-Sectional Descriptive Study (2014 to 2016). Open Access Library Journal, 5: e4762.

https://doi.org/10.4236/oalib.1104762

Received: July 6, 2018

Accepted: August 10, 2018

Published: August 13, 2018

Copyright $\odot 2018$ by authors and Open Access Library Inc.

This work is licensed under the Creative Commons Attribution International License (CC BY 4.0).

http://creativecommons.org/licenses/by/4.0/

\section{(c) (i) Open Access}

\begin{abstract}
Background: Adolescent pregnancy and childbirth remains a major public health problem that deserves special attention with regard to psychological and medical risks. Objective: The objective of this study was to determine the frequency and determinants of the course and evolution of pregnancy and childbirth in rural adolescents. Methods: This is a multicentre, retrospective and descriptive cross-sectional study carried out in the maternity wards of the Katombe Health Centre and the General Reference Hospital of Moba. The period from 2014 to 2016 was retained. The data were analysed using Epi Info 7.1 software program. Results: Teenage deliveries accounted for $13.2 \%$. The age mean of the adolescent was $17.3 \pm 1.3$ years, married (69.2\%), housewife (72.7\%), most of whom had at least one prenatal visits, primiparous (71.3\%) and the highest level of study is secondary (72.3\%). In the majority of cases, deliveries were dystocia (51.2\%) and by the lower ways (90.8\%). Maternal and neonatal mortality rates were respectively $1.7 \%$ and $3.4 \%$. The age of the adolescent determines the mode of delivery ( $\mathrm{p} 0.000)$, the delivery pathways ( $\mathrm{p}$ 0.040 ) and the postpartum trend ( $\mathrm{p} 0.000$ ). The adolescent under seventeen is significantly ( $\mathrm{p}$ 0.0006) at high risk. Age, parity, marital status, level of education, occupation of the author of the pregnancy, antenatal consultations visits
\end{abstract}


follow-up, and new-born delivery modes determine the postpartum mother's evolution. Similarly, neonatal outcome is determined by maternal age, marital status, level of education, occupation of the perpetrator, prenatal follow-up, maternal modes and ways of deliveries. Conclusion: Pregnancy is a high risk for adolescent girls in rural areas. In addition to this risk, the organizational difficulties of less well-equipped health structures are compounded. The modifiable determinants that influence the occurrence of this risk should be considered. The age of fewer than seventeen seems to be the most critical in terms of seriousness in rural areas.

\section{Subject Areas}

Public Health

\section{Keywords}

Pregnancy, Teenage, Delivery, Adolescent, DRC

\section{Introduction}

Adolescence is a period that the World Health Organization places between the ages of 10 and 19 years [1] [2]. It is characterized by the transition from the first appearance of secondary sexual characteristics (pubarche, telarche, menarche, etc.) to that of sexual maturity, the psychological processes and mechanisms of identification cease to be those of a child and become those of an adult, the transition from the state of total socio-economic independence to the state of relative independence [3]. Studies on adolescent health are increasing in number because of the interests of this barn in the population. Teenage pregnancy is a phenomenon that is becoming more and more frequent in the world [4] [5] [6] and which poses problems totally different from one another depending on the level of health development, the legal and cultural context, ethnicity And religious in which it is evoked [6] [7] [8]. This pregnancy may be unwanted or part of a deliberate personal project [9]. Nearly 16 million girls between the ages of 15 and 19 and some one million girls under the age of 15 give birth every year [6]. Pregnancy in this population group is a public health problem that deserves special attention given its psychosocial and medical complexity [10] [11] and the concerned risks associated with the fragility of the anatomo-physiological, psychological and sociological [3] [6] [12] [13] [14] [15]. Adolescent pregnancy remains one of the leading causes of maternal and child mortality, especially in developing countries, particularly in sub-Saharan Africa [3] [14] [16]. The rural environment pays a heavy price in terms of the frequency and consequences of pregnancy and childbirth than in the cities [6] [17] [18] [19] [20] [21].

In developing countries, such as the Democratic Republic of Congo, the risk of maternal and neonatal mortality is higher among teenage mothers than among adults [1] [4] [6] [22] [23] [24] [25]. According to several authors, this 
risk increases with decreasing maternal age [26] [27] [28] [29]. In some studies, especially in the West countries (developed), the prognostic differences between adolescents and adults are not significant [15]. For the World Health Organization, complications of pregnancy and childbirth are the second leading cause of death among girls aged $15-19$ worldwide, despite the regressive trend seen in recent years [6].

The problem of teenage pregnancy and childbirth is not unique to underdeveloped countries, characterized by precarious health conditions and high rates of early marriage and unwanted pregnancy [6] [14]. Countries such as the United States, France, Canada, Greece, Romania [17] [27] [29] [30] also have the same problems.

In the Democratic Republic of Congo (DRC), the Demographic and Health Survey 2013-2014 [31] reveals high age-specific fertility rates as early as $15-19$ years of age and low contraceptive use. For Tambwe, et al. [15] In the DRC, 13.9\% of adolescents gave birth at Lubumbashi University clinics; Iloki, et al. [32] mentions a low rate of $5.3 \%$ in the Republic of Congo while Tebeu, et al. [26] 24.0\% in Cameroon. In a number of studies, age, marital status, parity, nutrition, quality of antenatal surveillance [2] [6] [14] [15] [16] [26] [33], overall health status and ethno-tribal habits determine the course and purpose of pregnancy. Neonatal well-being, particularly among adolescent pregnant women and/or women, is of concern to health decision-makers. Studies on pregnancy and childbirth in the DRC are very few and mostly before 2010. It is in this perspective that this work (Contribution to the Study of Pregnancy and Childbirth In the rural adolescent) has been tackled to contribute to maternal and child health, especially in our environment. Its aim was to determine the frequency and determinants of the course and evolution of pregnancy and childbirth in rural adolescents. In addition to this primary objective, we have a secondary objective of providing solutions to the medical literature and our results in order to better guide the actions to be taken in adolescent health.

\section{Materials and Methods}

\subsection{SITE, Type and Period of Study}

This is a multicentre, retrospective and descriptive cross-sectional study carried out in the maternities services of the General Reference Hospital of Moba (GRH) and Katombe Health Centre. The study period was three years, from 2014 to 2016.

These hospital structures, which had been included in this work, are located in the present commune of Kirungu (Ex-city of Moba), territory of Moba, Province of Tanganyika in the South-East of the Democratic Republic of Congo. The choice of these two maternity units was motivated by their reception capacities and the high maternal and child health $(\mathrm{MCH})$ in our environment, where home deliveries slightly exceed those in hospitals. Moba is one of the 145 territories of the Democratic Republic of Congo (DRC) with an area of $24,500 \mathrm{~km}^{2}$ and an es- 
timated population of 609,406 inhabitants in 2015 [34]. There are 47 health centres and one HGR (without specialist in gynaecology and obstetrics) for two health zones: Moba (where the study was carried out) and Kansimba. The population lives mainly from agriculture and fishing on Lake Tanganyika. The Tabwa tribute (with matriarchal system) is locally more represented (more than $80 \%$ ) followed by Luba and Bemba.

\subsection{Inclusion Criteria and Sampling}

For this study, we included all adolescents under the age of twenty-nine, a maximum of nineteen years. The target of this study consisted of adolescent women who had given birth in the two structures. Adolescents were also obliged to respond to the parameters sought during the study period.

The sampling is simple probabilistic and random with the minimum size $(\mathrm{n}=$ 384) of the adolescent girls to be included with an accuracy set in advance in the statistical tables developed by using Schwartz methods: 95\% confidence level, maximum error 5\% [35]. Finally, a sample of 523 adolescent mothers who had given birth during the study period was selected for inclusion in this study: adolescent girl who gave birth to CS Katombe health centre and GRH of Moba during the study period and respondent to the desired variables.

\subsection{Data Collection}

Adolescent-related data were obtained from ANC records, childbirth registers, partographs and reference sheets, counter-referral and transfer (for adolescent girls who had transferred to Moba GRH).

In some cases, surgical procedures were reviewed to supplement data on high-level deliveries. A data collection sheet prepared in advance had helped to gather information about the adolescent girls targeted by this study.

\subsection{Operational Definitions}

- Parturient: Pregnant woman in childbirth.

- Adolescent: According to the WHO, it is a girl during the period of age between 10 and 19 years, that is to say less than twenty years [1].

- "Dariste": It is the bicycle driver who charges his services: transportation of goods and people.

- "Biker": In a local sense and taken in this study, it is the driver of Motorcycle (motorcyclist) who charges its services for public transport.

\subsection{Studied Parameters}

- Frequency of teenage births.

- Profile of teenage mothers: Age, educational level, adolescent professions, parity, antenatal consultations (ANC) and gestational age.

- The course of the delivery: types or modes of delivery (eutocia or dystocia), delivery route (vaginal or caesarean section). 
- Evolution and prognosis: Concern on the one hand the adolescents in post-partum and before the exit of the maternity; and on the other hand the new-born in early neonatal period. These include complications in childbirth and maternal mortality (number of deaths among adolescent women who gave birth) and early neonatal deaths.

\subsection{Statistical Processing and Data Analysis}

Data collected during the study period were encoded using a laptop computer on the Excel spread sheet (Microsoft, USA, 2010). Epi-Info 7.1 software program (Disease Control and Prevention, Atlanta, USA, 2011) was used to statistical analysis [36]. The results were presented in the form of tables and graphs (Figures) with numbers, percentages and location indicators (central trends: mean, extremes, median) and dispersion (variance and standard deviation). The relationship between the different parameters studied was done using the Pearson chi-square test. Means were analysed by ANOVA and the Bartlett Test. The determinants of childbirth in adolescence were evaluated using logistic regression. The significance level $p \leq 0.05$ was used to interpret all the tests involved in this study.

\subsection{Ethics of Research}

The data relating to this study were collected in strict respect of confidentiality. The authorization of the authorities managing the two health entities targeted by our study had been obtained. The structures that had transferred the parturient to the critical state were not disclosed.

\section{Results}

The results of our work on rural adolescents in Moba include the frequency, the profile (or characteristics) of the childbirth, the course of the childbirth and the postpartum period.

\subsection{Frequency of Adolescent Childbirth}

Of the three thousand nine hundred and sixty-six $(n=3966)$ deliveries made in the various hospital structures (Katombe health centre and GRH of Moba) selected for this work for the period 2014 to 2016, five hundred and twenty-three $(\mathrm{n}=523)$ cases of teenage births were recorded. These five hundred and twenty-three adolescents were the subject of this study, $13.2 \%$.

\subsection{Profile of Adolescent Girls in This Study}

They are mainly adolescents whose mean age was $17.3 \pm 1.3$ years with extremes ranging from 15 to 19 years, married $(n=362 ; 69.2 \%)$, housewives $(n=380$; $72.7 \%)$ and the highest level of education was completed or not completed ( $\mathrm{n}=$ 378; 72.3\%) (Table 1).

In our study series, the majority of adolescents had antenatal consultations or 
Table 1. Socio-demographic characteristics of adolescent girls relative to modes and ways (route) of delivery $(\mathrm{n}=523)$.

\begin{tabular}{|c|c|c|c|c|c|c|c|}
\hline \multirow[b]{2}{*}{ Characteristics } & \multirow{2}{*}{$\begin{array}{c}\text { Total number } \\
\text { of participants, } \\
n(\%)\end{array}$} & \multicolumn{3}{|c|}{ Delivery pattern $\mathbf{n}(\%)$} & \multicolumn{3}{|c|}{ Delivery pathways n (\%) } \\
\hline & & Eutocia & Dystocia & p-value & $\begin{array}{l}\text { Vaginal } \\
\text { delivery }\end{array}$ & $\begin{array}{c}\text { Caesarean } \\
\text { section }\end{array}$ & p-value \\
\hline \multicolumn{8}{|l|}{ Age (Years) } \\
\hline 15 & $48(9.2)$ & - & $48(100)$ & & $33(68.8)$ & $15(31.2)$ & \\
\hline 16 & $136(26.0)$ & $52(38.2)$ & $84(61.8)$ & & $129(94.9)$ & $7(5.2)$ & \\
\hline 17 & $89(17.0)$ & $53(59.6)$ & $36(40.4)$ & 0.0000 & $80(89.9)$ & $9(10.1)$ & 0.0401 \\
\hline 18 & $128(24.5)$ & $72(56.3)$ & $56(43.8)$ & & $126(98.4)$ & $2(1.6)$ & \\
\hline 19 & $122(23.3)$ & $78(63.9)$ & $44(36.1)$ & & $107(87.7)$ & $15(12.3)$ & \\
\hline Total n (\%) & $523(100)$ & $255(48.8)$ & $268(51.2)$ & & $475(90.8)$ & $48(9.2)$ & \\
\hline Means & 17.3 & & & & & & \\
\hline Sd. & 1.3 & & & & & & \\
\hline \multicolumn{8}{|l|}{ Civil status } \\
\hline Single & $118(22.6)$ & $52(44.1)$ & $66(55.9)$ & & $95(80.5)$ & $23(19.5)$ & \\
\hline Married & $362(69.2)$ & $186(51.4)$ & $176(48.6)$ & 0.7985 & $337(93.1)$ & $25(6.9)$ & 0.0000 \\
\hline Commonwealth & $43(8.2)$ & $17(39.5)$ & $26(60.5)$ & & $43(100)$ & - & \\
\hline \multicolumn{8}{|l|}{$\begin{array}{l}\text { Studies carried } \\
\text { out }\end{array}$} \\
\hline Illiterate & $25(4.8)$ & $8(32.0)$ & $17(68.0)$ & & $25(100)$ & - & \\
\hline Primary & $120(22.9)$ & $61(50.8)$ & $59(49.2)$ & 0,6793 & $104(86.7)$ & $16(13.3)$ & 0.4200 \\
\hline Secondary & $378(72.3)$ & $186(49.2)$ & $192(50.8)$ & & $346(91.5)$ & $32(8.5)$ & \\
\hline \multicolumn{8}{|l|}{ Profession } \\
\hline None & $51(9.8)$ & $9(17.6)$ & $42(82.4)$ & & $51(100)$ & - & \\
\hline Student & $83(15.9)$ & $50(60.2)$ & $33(39.8)$ & 0,0009 & 81 (97.6) & $2(2.4)$ & 0.8106 \\
\hline Teacher & $9(1.7)$ & $9(100)$ & - & & $9(100)$ & - & \\
\hline Household & $380(72.7)$ & $187(49.2)$ & $193(50.8)$ & & $334(87.9)$ & $46(12.1)$ & \\
\hline
\end{tabular}

Sd: Standard deviation.

visits at least once with means of $1.6 \pm 0.7$ sessions and the extremes of zero ( $\mathrm{n}=$ $8 ; 1.5 \%)$ to three ( $\mathrm{n}=71 ; 13.6 \%)$ (Table 3$)$. In terms of parity, adolescents were either primiparous $(\mathrm{n}=373 ; 71.3 \%)$ or paucipares $(\mathrm{n}=150 ; 28.7 \%)$. This predominance of primiparous on their pauciparous counterparts was statistically significant $(\mathrm{p}<0.05)$. Age was a determining factor in parity ( $p 0.000)$. Among the adolescent girls studied, the authors of the various pregnancies were mainly engaged in "Biker" $(n=157 ; 30.0 \%)$, student $(n=68 ; 13.0 \%)$, teacher $(n=59$; $11.3 \%)$ And cultivator $(\mathrm{n}=50 ; 9.6 \%)$ (Table 2$)$. In 76 cases (14.5\%) the occupation had not been determined. No teacher had made a pupil pregnant except pupils between them (38.2\%). The relationship between adolescent and pregnancy is not random but statistically significant (p 0.0064) (Table 2). 
Table 2. Adolescent and pregnant care profession.

\begin{tabular}{ccccccc}
\hline \multirow{2}{*}{$\begin{array}{c}\text { Author's } \\
\text { profession }\end{array}$} & $\begin{array}{c}\text { Total } \\
\text { number of }\end{array}$ & \multicolumn{5}{c}{ Adolescent Professions, n (\%) } \\
\cline { 3 - 7 } Of pregnancy & Participants, $\mathbf{n}(\%)$ & None & Student & Teacher & Housewife & p-value \\
\hline Bricklayer & $33(6.3)$ & - & $16(48.5)$ & - & $17(51.5)$ & \\
Cultivator & $50(9.6)$ & $8(16.0)$ & - & - & $42(84.0)$ & \\
Dariste* & $44(8.4)$ & $9(20.4)$ & $9(20.4)$ & $9(20.4)$ & $17(38.6)$ & \\
Student & $68(13.0)$ & $9(13.2)$ & $26(38.2)$ & - & $33(48.5)$ & 0.0043 \\
Biker* & $157(30.0)$ & $16(10.2)$ & $16(10.2)$ & - & $125(79.6)$ & \\
Fisher & $36(6.9)$ & - & $8(22.2)$ & - & $28(77.8)$ & \\
None & $76(14.5)$ & $9(11.8)$ & $8(10.5)$ & - & $59(77.6)$ & \\
Teacher & $59(11.3)$ & - & - & - & $59(100)$ & \\
Total & $\mathbf{5 2 3 ( 1 0 0 )}$ & $\mathbf{5 1 ( 9 . 8 )}$ & $\mathbf{8 3 ( 1 5 . 9 )}$ & $\mathbf{9 ( 1 . 7 )}$ & $\mathbf{3 8 0}(72.7)$ & \\
\hline
\end{tabular}

*See operational definitions.

\subsection{The Course of Childbirth in Adolescent Girls Studied}

In this study series on rural births, it was found that they were mostly dystocia $(\mathrm{n}=268 ; 51.2 \%)$ compared with $48.8 \%$ eutocia $(\mathrm{n}=255)$; vaginal delivery $(\mathrm{n}=$ $475 ; 90.8)$ versus $9.2 \%(n=48)$ for caesarean sections. The difference between the low and high pathways is significant ( $\mathrm{p}$ 0.0401) (Table 1).

Mechanical dystocia was encountered in $11.3 \%(n=59)$. Forty-four adolescents had complications, $8.4 \%$. Six episiotomies were performed, 13.6\% (Figure 3 ) and cervical tears $(n=15 ; 34.1 \%)$, perineal tears $(n=12 ; 27.3 \%)$, and haemorrhages of the delivery $(\mathrm{n}=11 ; 25.0 \%)$.

When analysing the results of our study, a statistically significant relationship was found between: age vs. modes and routes of delivery; Age vs. complications; vs. birth records (Table 1 and Figure 1); The profession of adolescent girls vs. modes of delivery (eutocia for teachers and dystocia for the unemployed); Follow-up of ANC vs. deliveries; Pathways and modes of delivery vs. trends in postpartum and new-born infants in the early neonatal period (Table 1, Table 3 and Table 4, Figure 2 and Figure 3).

At the age of fifteen, all cases of dystocia (100\%) were observed, and it was at this age that the upper lane was most in demand ( $\mathrm{n}=15 ; 1.2 \% ; \mathrm{p}<0.05)$. Also, at the age of sixteen, dystocia (61.8\%) had been significantly the most encountered. From the age of seventeen to nineteen years, eutocia deliveries were the most commonly seen in dystocia deliveries. This decreased decrease in dystocia was encountered with $63.9 \%$ of eutocia deliveries and $36.1 \%$ of obstructed births at age 19 (Table 1). All adolescent girls who did not follow ANCs were in the category of dystocia deliveries, although follow-up of ANC was not significantly for delivery modes ( $\mathrm{p}$ 0.5823) (Table 3). On the other hand, follow-up of ANC was statistically significant in relation to the delivery route ( $p$ 0.0095). The risk of caesarean section was found to decrease with the number of ANC sessions (Table 3). This study also showed (Figure 3) that 
Table 3. Delivery patterns and pathways in relation to antenatal visits.

\begin{tabular}{|c|c|c|c|c|c|c|}
\hline & \multirow{2}{*}{$\begin{array}{c}\text { Total number of } \\
\text { Participants, n (\%) }\end{array}$} & \multirow[b]{2}{*}{ None } & \multicolumn{4}{|c|}{ ANC tracking $n(\%)$} \\
\hline & & & 1 Times & 2 Times & 3 Times & $\mathrm{p}$-value \\
\hline \multicolumn{7}{|c|}{ Delivery Modes } \\
\hline Eutocia & $255(48.8)$ & - & $124(48.6)$ & $96(37.7)$ & $35(13.7)$ & \\
\hline Dystocia & $268(51.2)$ & $8(3.0)$ & $132(49.3)$ & $92(34.3)$ & $36(13.4)$ & 0.5823 \\
\hline $\mathrm{DD}^{*}$ & $209(40.0)$ & $5(2.4)$ & $105(50.2)$ & $82(39.2)$ & $17(8.1)$ & \\
\hline $\mathrm{DM}^{* *}$ & $59(11.3)$ & $3(5.1)$ & $27(45.8)$ & $10(16.9)$ & $19(32.2)$ & \\
\hline \multicolumn{7}{|c|}{ Delivery pathways } \\
\hline Lower & $475(90.8)$ & $1(0.21)$ & $232(48.8)$ & $178(37.5)$ & $64(13.5)$ & \\
\hline High & $48(9.2)$ & $7(14.6)$ & $24(50.0)$ & $10(20.8)$ & $7(14.6)$ & 0.0095 \\
\hline Total & $523(100)$ & $8(1.5)$ & $256(48.9)$ & $188(36.0)$ & $71(13.6)$ & \\
\hline
\end{tabular}

$\mathrm{DD}^{*}$ : Dynamic Dystocia, $\mathrm{DM}^{* *}$ : Mechanical dystocia.

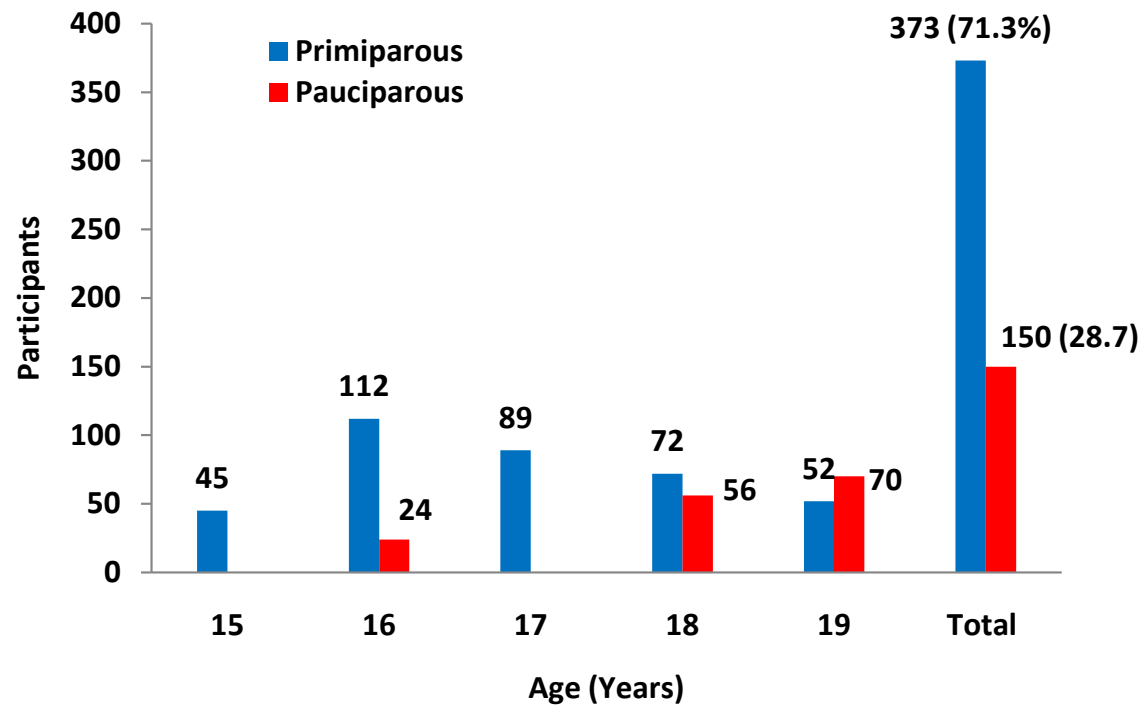

Figure 1 . Investigated by age and parity $(n=523)$.

premature infants were involved with $13.8 \%(n=72)$, while term infants accounted for only $82.4 \%(n=431)$.

\subsection{Evolution of Adolescents (Postpartum) and Neonates (Early Neonatal Period)}

In this study, the majority of adolescent girls had developed well ( $n=416$; $79.5 \%)$. However, in $18.7 \%(n=98)$ and $1.7 \%(n=9)$, poor outcomes were associated with poor morbidity and maternal death (Table 4). There is a significant difference ( $\mathrm{p}$ 0.0000) between birth modes and delivery patterns and postpartum adolescent outcomes. No cases of maternal death were found among eutocia deliveries. Mechanical dystocia were very much contributing to caesarean sections, poor changes and maternal deaths (Table 4). All nine deceased adolescents were 


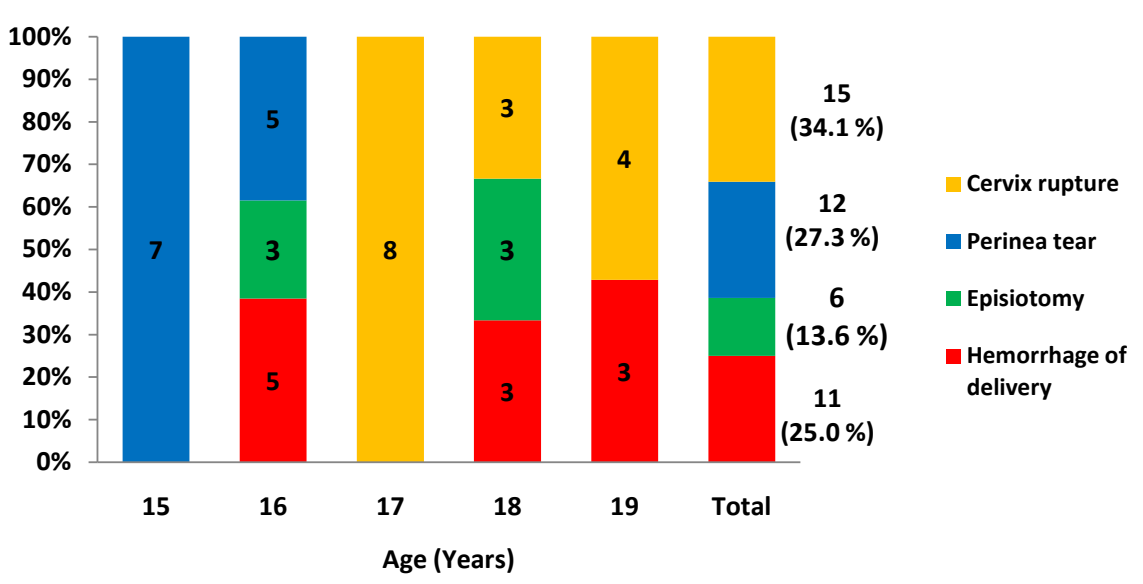

Figure 2. Age and obstetric complications among adolescents ( $\mathrm{n}=44$ of 523; 8.4\%).

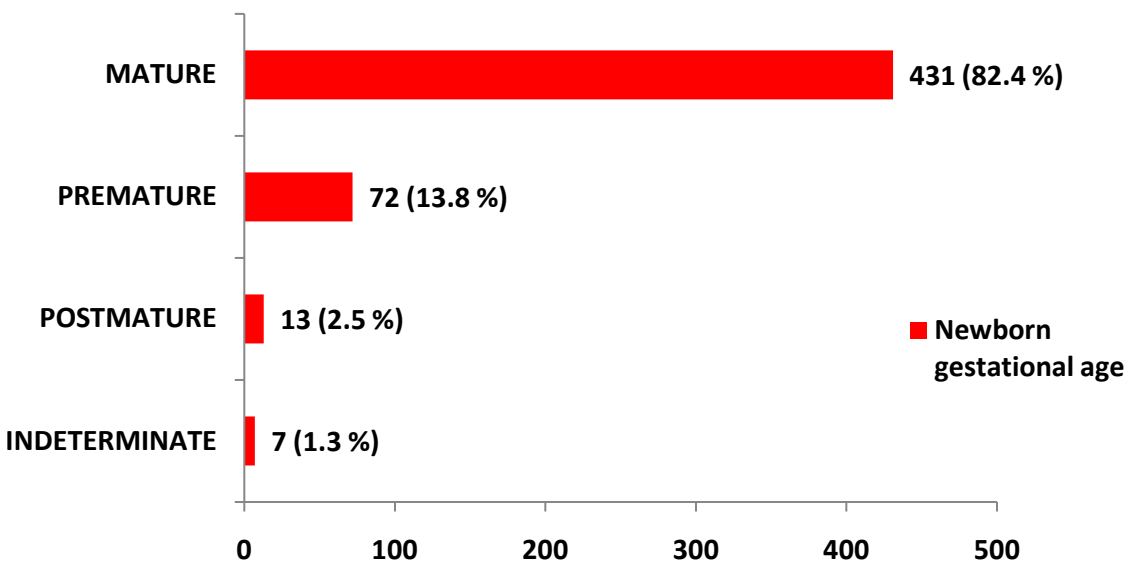

Figure 3. Newborns gestational ages $(n=523) ; \mathrm{p}=0.000$.

Table 4. Delivery patterns and pathways in relation to postpartum outcomes.

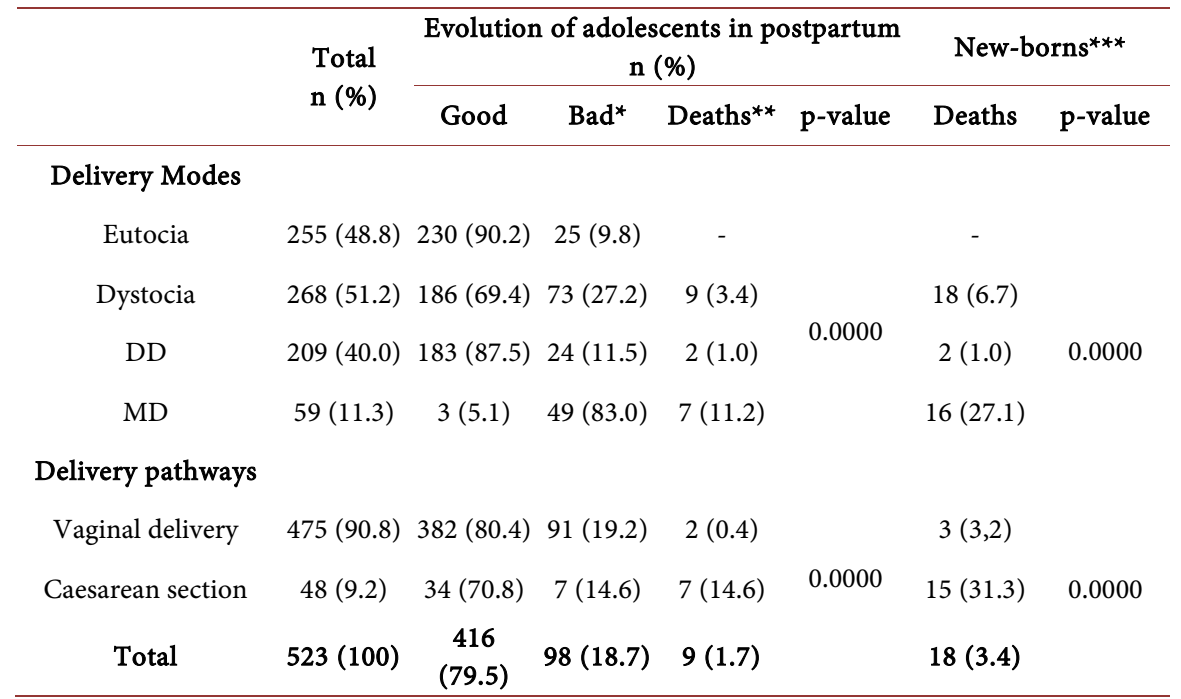

DD: Dynamic Dystocia; MD: Mechanical dystocia; *: Following the complications of the vaginal delivery, anaemia, Caesarean section and endometria's infections, strong pelvic pain; ${ }^{* *}$ : Uterine rupture (7) and Haemorrhage of delivery (2): late arrivals; ${ }^{* *}$ : The evolution was good in $75.3 \%(n=394)$ and bad $21.2 \%(n$ $=11$ ). 
19 years of age, primiparous and followed three ANC sessions.

Early neonatal mortality was associated with 18 new-borns (NB), or 3.4\%. All deceased new-borns came from dystocial deliveries and essentially from Caesarean section ( 15 of 18 cases, or $83.3 \%$ ).

The analysis of the quantitative variables (Table 5 and Table 6) gives the following information for adolescent girls in rural areas:

- Age and gender determine the pattern of deliveries;

- The age and follow-up of ANC determine the delivery pathways;

- Age, parity, marital status, level of education, profession of pregnancy, prenatal care, neonatal development, modes and routes of delivery Determine the evolution of the mother during childbirth and postpartum. Similarly, neonatal outcome is determined by maternal age, marital status, level of education, occupation of the perpetrator, prenatal follow-up, maternal Modes and ways of deliveries.

\section{Discussion}

The distribution of pregnancies during adolescence varies considerably between countries, amongst which the reasons mentioned include socio-cultural norms, level of the health system and education [37]-[43]. In 2011, the World Health Organization (WHO) published guidelines in partnership with the United Nations Population Fund (UNFPA) on how to prevent early pregnancies and their consequences [6]. These measures included: reducing the number of marriages before the age of eighteen; Raising public awareness in order to obtain support to reduce the number of pregnancies before the age of 20; Increase the use of contraception by adolescents exposed to unwanted pregnancies; Reduce the incidence of coercive sex and the number of unsafe abortions; And increase the

Table 5. Parameters studied and evolution of the mother and Newborns.

\begin{tabular}{|c|c|c|}
\hline Studies parameters & Mother's evolution & NB evolution \\
\hline $\operatorname{Age}^{x}$ & $0.0002^{*}$ & $0.0000^{*}$ \\
\hline Parity & $0.0468^{*}$ & 0.1015 \\
\hline Civil status ${ }^{*}$ & $0.0000^{*}$ & $0.0020^{*}$ \\
\hline Educational level $^{\mathbf{Y}}$ & $0.0400^{\star}$ & $0.0159^{*}$ \\
\hline Mother's occupation & 0.7739 & 0.5526 \\
\hline Occupation author of pregnancy ${ }^{*}$ & $0.0340^{*}$ & $0.0240^{*}$ \\
\hline ANC tracking ${ }^{*}$ & $0.0000^{*}$ & $0.0000^{*}$ \\
\hline Delivery modes ${ }^{*}$ & $0.0000^{*}$ & $0.0000^{*}$ \\
\hline Type of delivery ${ }^{x}$ & $0.0000^{*}$ & $0.0000^{*}$ \\
\hline Mother's evolution & - & $0.0000^{*}$ \\
\hline NB evolution & $0.0000^{*}$ & - \\
\hline
\end{tabular}

*: Significant at the threshold $\mathrm{p} \leq 0.05$; ${ }^{*}$ : Determining factors in both groups (mothers and newborns). 
Table 6. Quantitative variables.

\begin{tabular}{|c|c|c|c|c|c|c|c|c|c|c|c|}
\hline \multicolumn{2}{|c|}{ Variables } & \multicolumn{3}{|c|}{ Delivery pathways } & \multicolumn{3}{|c|}{ Delivery modes } & \multicolumn{4}{|c|}{$\begin{array}{l}\text { Maternal evolution in } \\
\text { postpartum }\end{array}$} \\
\hline & & Low $^{*}$ & $\mathrm{High}^{* *}$ & $\mathrm{p}$-value & Eutocia & Dystocia & $\mathrm{p}$-value & Good & $\mathrm{Bad}$ & Deaths & p-value \\
\hline \multirow{6}{*}{ 떤 } & Means & 17.3 & 16.9 & \multirow{6}{*}{0.040} & 17.7 & 16.9 & \multirow{6}{*}{0.000} & 17.4 & 16.4 & 19 & \multirow{6}{*}{0.000} \\
\hline & Sd. & 1.3 & 1.6 & & 1.1 & 1.3 & & 1.3 & 0.9 & 0.0 & \\
\hline & Min & 15 & 15 & & 16 & 15 & & 15 & 15 & 19 & \\
\hline & Med & 17.5 & 17 & & 18 & 17.5 & & 18 & 16 & 19 & \\
\hline & $\operatorname{Max}$ & 19 & 19 & & 19 & 19 & & 19 & 18 & 19 & \\
\hline & SE & 0.2 & 0.2 & & 0.1 & 0.1 & & 0.418 & 0.418 & 0.418 & \\
\hline \multirow{6}{*}{ 酉 } & Means & 1.3 & 1.2 & \multirow{6}{*}{0.090} & 1.5 & 1.4 & & 1.3 & 1.2 & 1 & \multirow{6}{*}{0.047} \\
\hline & Sd. & 0.5 & 0.4 & & 0.6 & 0.3 & & 0.5 & 0.5 & 0.0 & \\
\hline & Min & 1 & 1 & & 1 & 1 & & 1 & 1 & 1 & \\
\hline & Med & 1 & 1.5 & & 1.5 & 1 & 0.000 & 1.5 & 1.5 & 1 & \\
\hline & $\operatorname{Max}$ & 3 & 3 & & 2 & 1 & & 3 & 3 & 1 & \\
\hline & SE & 0.07 & 0.07 & & 0.04 & 0.04 & & 0.17 & 0.17 & 0.17 & \\
\hline \multirow{6}{*}{ 岁 } & Means & 1.6 & 1.4 & \multirow{5}{*}{0.009} & 1.7 & 1.6 & \multirow{6}{*}{0.284} & 1.7 & 1.3 & 3 & \multirow{6}{*}{0.000} \\
\hline & Sd. & 0.7 & 0.9 & & 0.7 & 0.8 & & 0.7 & 0.7 & 0.0 & \\
\hline & Min & 1 & 1 & & 1 & 0.0 & & 1 & 0.0 & 3 & \\
\hline & Med & 2 & 1 & & 2.5 & 1.5 & & 2 & 1.5 & 3 & \\
\hline & Max & 3 & 3 & & 3 & 3 & & 3 & 3 & 3 & \\
\hline & SE & 0.1 & 0.1 & & 0.06 & 0.06 & & 0.235 & 0.235 & 0.235 & \\
\hline
\end{tabular}

SE: standard Error; Max: Maximum; Min: Minimum; Sd: standard Deviation; Med: Median; ${ }^{\star}$ Vaginal delivery; ${ }^{* *}$ Caesarian section.

use of quality care before, during and after childbirth. [6] These different measures pose problems for their application in virtually all countries, hence the persistence of the phenomenon of pregnancy and childbirth among adolescents [12] [15] [16]. Adolescence is above all a period of maturation. This maturation occurs physically as well as socially and influences the relationships between young people as well as with the people around them. If the process unfolds normally, it is a positive force and promotes the development of the adolescent on other levels. Very often the signs of sexual maturation (menarche, telarche and pubarche) appear before the psychological or social maturity and even before the complete physical maturity. This means that young girls are able to conceive a child without being physically or psychologically ready. Maternity during adolescence, especially in early adolescence, therefore involves considerable health risks [5] [44]. There, our study contributes to the teenager's health.

\subsection{Frequency of Adolescent Childbirth}

In our study series, teenage deliveries account for $13.2 \%$. This frequency in Congolese rural Moba is in the range of $6 \%$ to $25 \%$ evoked in the literature [4] 
and close to the $13.9 \%$ that Tambwe, et al. [15] had evoked in the city of Lubumbashi, in the Democratic Republic of Congo. However, it is superior to the results encountered by Kemfang, et al. in Cameroon, Hamada, et al. [21] in Morocco and Tebeu, et al. [45] in Cameroon with 2.84\%, 2.6\% and 6.6\% respectively.

In some studies in South Africa, India and Cameroon, rates are higher than ours, with proportions even reaching 26.5\% [4] [26] [46] [47].

Frequency variability can be found in different regions of the same country: Cameroon [4] [26] [45].

The reasons for the persistence of deliveries in this population group (adolescents) remain the same in our analysis: sociocultural values in favour of fertility and desire of many children ("symbol of wealth"), early relationships, the lack of quality sex education, the lesser use of contraceptive methods and the greater physical development of some girls than their counterparts. [4] [32] [47] [48].

One fact seems to be peculiar in regard to the sociocultural habits of our milieu: matriarchy. The matriarchal system would be an additive element in favor of teenage pregnancies. In discussions with some girls, it is easy to see the willingness of some girls to leave at least one child to the parents before leaving the paternal roof. The absence of pregnancy is experienced more dramatically than the occurrence of a child out of wedlock. Precociousness of having a child would thus enable the girl to be sure of the possibility of conceiving a child.

The proportion of adolescent girls in pregnancy and childbirth can be an indicator of population growth and the risk of contracting STIs and HIV [4] [5] [41] [46] [49].

Several studies consider Africa as the region of the planet where more adolescent mothers are generally found, with all the consequences that may occur [6] [12] [40] [41]. However, it is good practice to qualify this approach with pregnancies of this segment of the population which aborted by legal authorization of voluntary interruptions of pregnancy in some industrialized countries, differently from the several regions of the African continent where abortions are Ill-received.

Many countries have risen the minimum legal age for marriage, but this has little effect in traditional societies where the only appropriate role for women is considered to be early marriage and having children. Indeed, in these societies, high fertility makes women more important, so the sooner they begin to have children, the more they will be appreciated by society.

People who start having children at an early age usually have more children at more frequent intervals than others. In addition to the harmful effects this may have on the health of mothers and children, this also has implications for population growth [5].

\subsection{Profile of Adolescent Girls Studied}

\subsubsection{Age}

Adolescent pregnancy and childbirth in our study series are those of mean age at 
$17.3 \pm 1.3$ years and extremes ranging from 15 to 19 years. No teenage girl was under the age of fifteen, unlike some studies [23] [26] [45]. Our average age is close to Kemfang, et al. [50] with $17.76 \pm 1.30$ years. We believe that the effect of having no teenager under the age of 15 in our series would be a coincidence. A larger sample than ours and under the same conditions would have adolescents under the age of fifteen. These arguments do not, however, prevent us from remembering that this age is greatly associated with dystocial and high-level deliveries.

\subsubsection{Civil Status (Marital Status)}

The marital status of our adolescent girls was dominated by the married (69.2\%) followed by the unmarried [24]. Contrary to these results, some authors refer to singles [22] [23]. This difference would be due to the fact that among us some teenage girls often tend to pretend that they have become pregnant by legitimate marriage with the payment of the dowry. As a result, they tend to consider themselves married and that new-borns have parents recognized by society. Indeed, the share of false testimonies related to marital status is not to be neglected for a retrospective study.

\subsubsection{Level of Education (Studies)}

The level of education has been mentioned by several authors as a factor associated with the occurrence of teenage pregnancy [22] [23] [24]. In this study, the highest level of education was secondary (72.3\%) [23]. Illiterates represent only $4.8 \%$. The reason is simple. The city of Moba was once known as one of the areas with low enrolment, especially for young girls. The various mobilizations for adolescent girls with the support of international partners would have helped to improve this level of education, but efforts still need to be made.

\subsubsection{Occupation}

In rural Moba, the majority of teenagers claim to be in the category of housewives. In fact, we dare to believe that many are without a profession. Staying at home to keep children is one of the characteristics of our traditional societies. As a result, women consider staying at home to manage children as a profession.

Parity: Primiparous animals were the most common in adolescent births with $71.3 \%$ followed by paucipares alone $(28.7 \%)$. This result has been met by several authors [23]. It is natural that teenage girls are much more in the rank of primiparous in terms of the age that facilitates this probability.

\subsection{Pregnancy Monitoring (Antenatal Visits)}

Pregnancy is a physiological process between fertilization and childbirth. It is an important part of the human reproductive system. The majority of adolescent girls in our study series had at least one follow-up ANC (98.5\%). The average was $1.6 \pm 0.7$ sessions and no adolescent had exceeded three prenatal visits. Overall, the follow-up was no better than the standards advocated by WHO and the national reproductive health program from a qualitative and quantitative 
standpoint.

Pregnancy monitoring is critical for maternal and foetal health because it helps to identify high-risk pregnancy factors [51] and to predict good progress in pregnancy and childbirth.

In several studies, the lack of follow-up of pregnancy was evoked and considered as predisposing adolescents to a bad evolution during the gravid period [40] [42] [48]. In our work, there is a significant difference between ANCs and the delivery route.

For Hamada, et al. [21], age-related risks are associated with later screening for pregnancy complications for adolescent girls who did not follow ANC. To this effect, it should be noted that even older women ( $\geq 20$ years) have difficulties in following their pregnancies in several countries [21].

\subsection{Procedure of Childbirth}

\subsubsection{Mode of Delivery}

The mode of delivery is slightly dominated by dystocial deliveries $(51.2 \%)$, unlike some authors [15] [16] [52]. Dystocia mainly involves adolescents under the age of 17 years and was the basis of the mortality encountered in this study.

Indeed, age was found to be a determining factor in relation to the mode of delivery and the postpartum evolution (p-value 0.000). It should be assumed that the anatomo-physiological immaturity of the adolescent, in particular her pelvis, is a factor of dystocia [3] [6] [21]. This experience of the maternal pelvis is correlated with parity, which has been found to be a determining factor in the mode of delivery, and to high frequencies of instrumental extraction [21]. Other factors determining the mode of delivery are occupation ( $p$ 0.0009) and parity $(p$ $0.0000)$.

\subsubsection{Childbirth}

The majority of deliveries were significantly low (90.8\%). Caesarean sections represent $9.2 \%$ of our teenage girls, somewhat higher than some authors [15] [16] [21] [47] [52] and less than the 24.8\% of Adzaxo, et al. and Adama, et al. [53] [54]. The role of age and mechanical dystocia should be emphasized. In this study, age ( $p$ 0.0401), marital status ( $p$ 0.0000) and follow-up of ANC ( $p$ 0.0095) determine the route of delivery for adolescent girls studied. Most new-born deaths were in the high-birth category ( $p$ 0.0000).

\subsubsection{Gestational Age}

In this study, we found $13.8 \%$ prematurity compared to $2.5 \%$ post-term infants (more than 42 weeks of amenorrhoea) and over-term (over 40 weeks of amenorrhea). The rate of preterm deliveries appears to be high compared to some studies in adolescents [21] and lower than others [55]. It should be stressed that in the tropical environment where we are, the place of malaria is not to be neglected. The prevalence of preterm infants in the general population was variably assessed: $11.8 \%$ by Chiesa, et al. [56], 21.05\% by Tietche, et al. [57] and 
$33.6 \%$ by Nagalo, et al. [58]. A case-control cohort study would be needed to determine whether the adolescent is at risk compared to adult women.

\subsection{Adolescent Complications and Mortality}

Any pregnant woman is exposed to some degree of risk and complications related to pregnancy and childbirth. In our study series, forty-four adolescents presented complications, some of which delayed the development of the foetal mobile and indicate episiotomies.

We have the cervical tears of the cervix, the tears of the perineum, and the haemorrhages of the delivery. This same observation has been mentioned in different proportions by some authors [15] [47]. Some authors also mention anaemia's [21] which were not sought in our study series.

A comparative study between adolescents and controls in Morocco [21] did not find the increased risk in the aftermath between teenage and adult women.

We found that there is a significant difference between the modes and routes of childbirth in adolescence and the evolution of adolescents during childbirth and postpartum.

Adolescent mortality was in the order of $1.7 \%$ or $17 \%$. It is restricted to adolescents aged 19 years with dystocia (Table 4). We are not in a position to answer in this study whether complications related to the low-pathway are related to the purpose of obstetric care or to the condition of adolescent girls. Births are predominantly managed by traditional nurses and midwives who have not studied the midwifery option.

However, this adolescent mortality does not appear to be any different than for the adult population. Hence, the utility of undertaking the case-control studies in our environments to complete the limits of our results. Nevertheless, this first study in our environment reveals that age, parity, marital status, educational level, occupation of the author of the pregnancy, follow-up of prenatal consultations, The mother's postpartum development. There is a significant association between maternal and neonatal changes ( $p$ 0.0000).

\subsection{Early Neonatal Mortality}

During our study period, 18 new-borns had died during the early neonatal period, or $3.4 \%$. In fact, all registered cases of early neonatal mortality were in the category of obstructed labour and 15 new-borns out of 18 who died were born by Caesarean section.

In this series of studies, the age of the adolescent, the pathway and mode of delivery determine the evolution of the adolescent mother's new-born child.

These results demonstrate that adolescent mothers are at high risk of death despite the fact that this proportion of neonatal deaths appears to be comparable to the births of adult women [59] [60]. This high incidence of neonatal deaths after caesarean section may also indicate the poor quality of care due to the lack of specialists (obstetrician and neonatologist) and neonatal resuscitation equip- 
ment. Indeed, in the two structures where this study was carried out there is no functional incubator, heating table and oxygen therapy. From this point of view, this study is an inquiry to the health authorities and partners in health for the women and the new-borns of the health zone of Moba. At logistic regression, neonatal outcome is determined by maternal age, marital status, level of education, occupation of the author of the pregnancy, follow-up of prenatal consultations, maternal progression, Modes and pathways of deliveries.

\subsection{Limitations of This Study}

This study has limitations with regard to the comparison of study parameters between adolescent and adult parturient. Our contribution focused only on adolescent girls. We dare to believe that it is necessary in the future to carry out studies comparing teenage and adult mothers to identify the differences between the two groups. Nevertheless, the information obtained in this study allows us to have the necessary information on the evolution of teenage pregnancies and deliveries in our environment.

\section{Conclusion}

Teenage pregnancy and childbirth remain a major public health problem that deserves special attention because of the potential risks. These risks are associated with high morbidity and mortality associated with the adolescent's age and the quality of obstetric care in the care. This study found that the frequency of births among teenagers was $13.2 \%$ with maternal and neonatal mortality rates of $1.7 \%$ and $3.4 \%$ respectively. The age of 17 years is at greatest risk for this category of the population because it determines the mode of delivery, the delivery route and the postpartum evolution. The determinants of maternal progression were age, parity, marital status, educational attainment, occupation of the author of the pregnancy, follow-up of prenatal consultations, modes of delivery. Similarly, neonatal outcome is determined by maternal age, marital status, level of education, occupation of the perpetrator, prenatal follow-up, maternal Modes and ways of deliveries. Pregnancy in rural adolescent girls is at high risk. This risk is related to the youngest age of the adolescent and our limited capacities in the care of mothers and new-borns. Efforts should be made at all levels of decision-making to avoid early pregnancies and improve our care of mothers and children in order to achieve the goals set by the World Health Organization.

\section{Acknowledgements}

The authors sincerely thank all maternity nurses at the Katombe Health Centre and Moba General Reference Hospital for their participation in the data collection.

\section{Conflict of Interest}

The authors do not declare any conflicts of interest in connection with this 
study. This study was funded by the authors' own contributions.

\section{References}

[1] WHO (1975) Pregnancy and Abortion in Adolescence. Geneva, 58.

[2] Blondel, B. (1986) A propos de la grossesse chez l'adolescence. Journal de Gynécologie Obstétrique et Biologie de la Reproduction, 15, 39.

[3] Colline Epouse Maurice, O. (2000) Grossesse et accouchement chez l'adolescente de moins de 16 ans en Guyane. Thèse de Médecine, Faculté de Médecine de Nancy, Université Henri Poincaré-Nancy 1, France.

[4] Tebeu, P.M., Tantchou, J., Obama Abena, M.T., Mevoula Onala, D. and Leke, R.J.I. (2006) Accouchement des adolescentes à l'extrême nord du Cameroun: Des proportions inadmissibles. Revue Médicale de Liège, 61, 124-127.

[5] OMS (1989) La santé des jeunes, avoir pour agir: Les jeunes, sexualité et reproduction. OMS, Genève, 1-12.

[6] OMS (2014) La grossesse chez les adolescentes, Aide-mémoire. 364.

[7] Stevenson, W., Maton, K.I. and Tetis, D.M. (1998) School Importance and Dropant among Pregnant Adolescents. Journal of Adolescent Health, 22, 376-382.

https://doi.org/10.1016/S1054-139X(97)00273-5

[8] Teagle, S.E. and Brindis, C.D. (1998) Substance Use among Pregnant Adolescents: A Comparison of Self-Reported and Provider Perception. Journal of Adolescent Health, 22, 229-238. https://doi.org/10.1016/S1054-139X(97)00170-5

[9] Archie, C.L., Anderson, M.M. and Gruber, E.L. (1997) Positive Smoking History as a Preliminary Screening Device for Substance Use in Pregnant Adolescents. Journal of Pediatric and Adolescent Gynecology, 10, 13-17. https://doi.org/10.1016/S1083-3188(97)70038-X

[10] Djadou, K.-E., Kanassoua, K., Douki, K., Sededji, A., Atakouma, D.-Y. and Agbere, A.D. (2010) Mortalité et morbidité des adolescentes à l'hôpital de Tsevie (Togo). Journal de Pédiatrie et Puériculture, 23, 191-197. https://doi.org/10.1016/j.jpp.2010.04.004

[11] Mignot, C. (1999) La grossesse chez l'adolescente. Journal de Pédiatrie et Puériculture, 12, 353-358. https://doi.org/10.1016/S0987-7983(99)80177-7

[12] OMS (2012) Mariages précoces, grossesses chez les adolescentes et les jeunes femmes. Rapport du Secrétariat, $65^{\text {ème }}$ Assemblée Mondiale de la Santé, A 65/13, $1-5$.

[13] Soula, O., Carles, G., Largeaud, M., El Guindi, W. and Montoya, Y. (2006) Grossesse et accouchement chez les adolescentes de moins de 15 ans, Etude de 181 cas en Guyane Françoise. Journal de Gynécologie Obstétrique et Biologie de la Reproduction, 35, 53-61. https://doi.org/10.1016/S0368-2315(06)76372-4

[14] Anta Ta Dia (2002) Facteurs pronostiques des complications de la grossesse et de l'accouchement chez l'adolescente et son nouveau-né au Sénégal. Cahiers d’Etudes et de Recherches Francophones/ Santé, 11, 221-228.

[15] Tambwe, M.N.K., Kalenga, M.K. and Kakoma, Z.Z. (1999) La parturition chez les adolescentes à la clinique Universitaire de Lubumbashi (Congo). Revue Française de Gynécologie et do Obstétrique, 94, 370-383.

[16] Laghzaoui Boukaidi, M., Bouhya, S., Bennani, O., Hermas, S., Soummani, A. and Aderdour, M. (2002) Grossesse et accouchement chez l'adolescente. Maroc Médical, 24, 182-185.

[17] Faucher, P., Dappe, S. and Medelenat, P. (2002) Maternité à l'adolescence: Analyse 
obstétricale et revue de l'influence des facteurs culturels, socioéconomiques et psychologiques à partir d'une étude rétrospective de 62 dossiers. Gynécologie Obstétrique et Fertilité, 30, 944-952. https://doi.org/10.1016/S1297-9589(02)00497-6

[18] Nyakube, G.A. (2010) Factors Associated with Adolescent Pregnancies among Secondary School Students: A Study from Tanzania. Dar es Salam Medical Student's Journal, 16, 31-33.

[19] Prual, A. (1999) Grossesse et accouchement en Afrique de l'Ouest: Une maternité à haut risque. Santé Publique, 11, 155-165.

[20] Traoré, B., Thera, T.A., Kokaina, C., Beye, S.A., Mounkoro, N., Teguete, I. and Dolo, A. (2010) Mortalité maternelle au service de gynécologie-Obstétrique du centre hospitalier régional de Ségou au Mali: Etude rétrospective sur 138 cas. Mali Médical, 25, 42-47.

[21] Hamada, H., Zaki, A., Nejjar, H., Filali, A., Chraibi, C., Bezad, R., et al. (2004) Grossesse et accouchement chez l'adolescente: Caractéristiques et profil. Journal de Gynécologie Obstétrique et Biologie de la Reproduction, 33, 607-614. https://doi.org/10.1016/S0368-2315(04)96601-X

[22] Rwenge Mburano, J.-R. and Tchamgoue-Nguemaleu, H.-B. (2011) Facteurs Sociaux de l'utilisation des Services de soins Obstétricaux Parmi les Adolescentes Camerounaises. African Journal of Reproductive Health, 15, 81-92.

[23] Ayuba Isa, I. and Gani, O. (2012) Outcome of Teenage Pregnancy in the Niger Delta of Nigeria. Ethiopian Journal of Health Sciences, 22, 45-50.

[24] Onoh Chukwudi, R., Ezeonu Olisaemeka, P., Anozie Okechukwu, B., Uzoma Esike, C.-O., Obuna Johnson, A., Egbuji Chukwuma, et al. (2014) Outcome of Teenage Pregnancy at a Tertiary Hospital in Abakaliki Southeast Nigeria. Journal of Basic and Clinical Reproductive Sciences, 3, 22-26. https://doi.org/10.4103/2278-960X.129274

[25] Vangeenderbuysen, C. and Lamina Souley, F. (2001) La grossesse chez la célibataire à Niamey (Niger). Revue Africaine de Santé Reproduction, 5, 98-104.

[26] Tebeu, P.M., Kouam, L., Obama, A.M.T., Wamba, T.M., Ngassa, P., Kamdom Moyo, et al. (2002) Quel serait l'âge de la parité précoce chez les adolescentes au CHU de Yaoundé (Cameroun). Médecine d Afrique Noire, 49, 439-442.

[27] Dedecker, F., Baillien Court, T., Barau, G., Fortier, D., Robillard, P.-Y., Roger-Wolter, M.M., et al. (2005) Etude des facteurs de risques obstétricaux dans le suivi de 365 grossesses primipares adolescentes à l'Ile de la Réunion. Journal de Gynécologie Obstétrique et Biologie de la Reproduction, 34, 694-701. https://doi.org/10.1016/S0368-2315(05)82903-5

[28] Babson, S.G. and Benson, R.C. (1994) Le fotus à haut risque et les facteurs associés, pratique du haut risque obstétrical et néonatal. Editions Masson, 9-20.

[29] Amini, S.B., Catalano, P.M., Dierker, L.T. and Man, L.J. (1996) Births to Teenager: Trends and Obstetric Outcome. Obstetrics and Gynecology, 87, 668-674. https://doi.org/10.1016/0029-7844(96)00007-5

[30] Socolov, D.G., Iorga, M., Carauleanu, A., Ilea, C., Blidaru, I., Boiculese, L., et al. (2017) Pregnancy during Adolescence and Associated Risks: An 8-Years Hospital Based Cohort Study (2007-2014) in Romania, the Country with the Highest Rate of Teenage Pregnancy in Europe. Biomed Research International, 2017, Article ID: 9205016. https://doi.org/10.1155/2017/9205016

[31] RDC-EDS II (2014) Enquête démographique et de santé 2013-2014: Rapport Préliminaire. Mai, 21-41.

[32] Iloki, L.-H., Koubaka, R., Itoua, C. and Mbemba Moutounou, G.-M. (2004) Grossesse 
et accouchement chez l'adolescente au Congo. Journal de Gynécologie Obstétrique et Biologie de la Reproduction, 33, 37-42. https://doi.org/10.1016/S0368-2315(04)96310-7

[33] Fédération Nationale des observatoires régionaux de la santé (FNORS) (1997) Autour de la grossesse, la santé observée dans les régions de France, synthèse nationale des tableaux de bords régionaux sur la santé, chapitre 3. FNORS, 9-11.

[34] (2016) CAID/RDC: Territoire de Moba, Cellule d'analyse des indicateurs de développement.

https://www.caid.cd.index.php/donnees-par-province-administrative-province-de-t anganyika/territoire-d-moba/?selecteur=fiche

[35] Lwanga, S.K. and Lemeshow, S. (1991) Détermination de la taille d'un échantillon dans les études sanometriques: Manuel pratique, NLM-WA 950. Organisation Mondiale de la Sante Genève, 33-35.

[36] Dean, A.G., Arner, T.G., Sangam, C.G., Sunki, G.C., Friedman, R., Lantinga, M., et al. (2011) Epi InfoTM, a Database and Statistics Program for Public Health Professionals. Centers for Disease Control and Prevention, Atlanta, Georgia, USA.

[37] Adam, I., Babiker, S., Mohmmed, A.A., Salih, M.M., Prins, H.M. and Zaki, M.Z. (2007) Low Body Mass Index, Anaemia and Poor Perinatal Outcome in a Rural Hospital in Eastern Sudan. Journal of Tropical Pediatrics, 54, 202-204. https://doi.org/10.1093/tropej/fmm110

[38] Feresu, S.A., Harlow, S.D., Welch, K. and Gillespie, B.W. (2004) Incidence of and Socio-Demographic Risk Factors for Stillbirth, Preterm Birth and Low Birthweight among Zimbabwean Women. Paediatric and Perinatal Epidemiology, 18, 154-163. https://doi.org/10.1111/j.1365-3016.2003.00539.x

[39] Loto, O.M., Ezechi, O.C., Kalu, B.K., Loto, A., Ezechi, L. and Ogunniyi, S.O. (2004) Poor Obstetric Performance of Teenagers: Is It Age- or Quality of Care-Related? Journal of Obstetrics and Gynecology, 24, 395-398. https://doi.org/10.1080/01443610410001685529

[40] Magadi, M. (2006) Poor Pregnancy Outcomes among Adolescent in South Nyanza Region of Kenyan. African Journal of Reproductive Health, 10, 26-38. https://doi.org/10.2307/30032441

[41] Sekiwunga, R., Reynolds and Whyte, S. (2009) Poor Parenting: Teenagers Views on Adolescent Pregnancies in Eastern Uganda. African Journal of Reproductive Health, 13, 113-127.

[42] Sulaiman, S., Othman, S., Razali, N. and Hassan, J. (2013) Obstetric and Perinatal Outcome in Teenage Pregnancies. South African Journal of Obstetrics and Gynecology, 19, 77-80. https://doi.org/10.7196/sajog.679

[43] Elshibly, A.M. and Schmalisch, G. (2008) The Effect of Maternal Anthropometric Characteristics and Social Factors on Gestational Age and Birth Weight in Sudanese Newborn Infants. BMC Public Health, 8, 244. https://doi.org/10.1186/1471-2458-8-244

[44] Gharoro, E.P. and Igbafe, A.A. (2002) Maternal Age First Birth and Obstetric Outcome. Nigerian Journal of Clinical Practice, 5, 20-24.

[45] Tebeu, P.M., Obama, M.T., Kouam, L., Major, A.L., Lüdicke, F. and Doh, A.S. (2004) Risque de l'augmentation de la contribution des adolescentes dans les accouchements avec la baisse du pouvoir d'achat. Médecine d'Afrique Noire, 51, 673-674.

[46] Paquette, D. and Morrisson, D. (1999) Un profil descriptif de 100 mères adolescentes: étude préliminaire dans le cadre du projet La mère veille. Institut de Recherche pour 
le Développement Social des Jeunes, Aout, 2-7.

[47] Gandzien, P.C. and Ekoundzola, J.R. (2005) Grossesse et accouchement chez l'adolescente à la maternité de Talangaï, Brazzaville (Congo). Médecine d Afrique Noire, 52, 429-433.

[48] Janky, E., Gallais, A. and Landre, M. (1996) Généralités sur la grossesse et l'accouchement chez l'adolescente. Encyclopédie Médicale-Chirurgicale-Gynécologique et Obstétricale, 5-016-D-10, 6-7.

[49] Alemayehut, T., Haidar, J. and Habte, D. (2010) Utilization of Antenatal Care Services among Teenagers in Ethiopian: A Cross Sectional Study. Ethiopian Journal of Health Development, 24, 221-225.

[50] Kemfang Ngowa, J.D., Kasia, J.M., Pisoh, W.D., Ngassam, A. and Noa, C. (2015) Obstetrical and Perinatal Outcomes of Adolescent Pregnancies in Cameroon: A Retrospective Cohort Study at the Yaoundé General Hospital. Open Journal of $O b$ stetrics and Gynecology, 5, 88-93. https://doi.org/10.4236/ojog.2015.52012

[51] Bouafia, N., Mahjoub, M., Nouira, A., Ben Aissa, R., Saïdi, H., Guedana, N. and Njah, M. (2013) Profil épidémiologique des grossesses à risque à Sousse (Tunisie). Eastern Mediterranean Health Journal, 19, 465-473. https://doi.org/10.26719/2013.19.5.465

[52] Lao, T.T. and Ho, L.F. (1997) Obstetric Implications of Teenage Pregnancy. Human Reproduction, 12, 2303-2305. https://doi.org/10.1093/humrep/12.10.2303

[53] Adzaxo, K., Awassi, A.N., Toure-Coulibaly, K., Adjobi, R.E. and Grenebei, R. (1985) Facteurs de risque de la parturition chez l'adolescente: A propos de 329 observations. Journal de Gynécologie Obstétrique et Biologie de la Reproduction, 14, 122-129.

[54] Adama-Hondegla, A., Bonin, K., Aboubakari, A., Modji, S. and Akpadza, K. (2012) Aspects épidémiologique, clinique et pronostic de l'accouchement des adolescentes à Lomé en 2010. Journal de la Recherche Scientifique de IUniversité de Lomé (Togo), 14, 453. https://www.ajol.info/index.php/jrsul/article/view/138736

[55] Suraiya, S.K., Al-Sibai, M.H. and Al-Suleiman, S.A. (1986) Obstetrics Implications of Pregnancy in Adolescence. Acta Obstetricia et Gynecologica Scandinavica, 65, 57-61. https://doi.org/10.3109/00016348609158231

[56] Chiesa Moutandou-Mboumba, S. and Mounanga, M. (1999) Le prématuré au Gabon: problème médical et/ou de société? Médecine d Afrique Noire, 46, 435-441.

[57] Tietche, F., Ngoufack, G., Kago, I., Mbonda, E., Koki Ndombo, P.O. and Leke, R.I. (1998) Facteurs étiologiques associes au retard de croissance intra-utérine à Yaoundé (Cameroun): Etude préliminaire. Médecine d’ Afrique Noire, 45, 377-380.

[58] Nagalo, K., Dao, F., Badiel, R., Sawadogo, O., Housseini Tall, F.H. and Ye, D. (2015) Epidemiological, Clinical and Prognostic Aspects of Preterm Birth over 10 Years in Ouagadougou (Burkina Faso). Journal of Pediatric Sciences, 7, e231. https://doi.org/10.17334/jps.69907

[59] Kambale, R., Maseka, A., Bwija, J., Bapolisi, W., Bashi, J., Masumbuko, B., et al. (2016) Facteurs de risque associés à la mortalité néonatale dans un hôpital de niveau tertiaire en République Démocratique du Congo. Médecine d Afrique Noire, 63, 401-408.

[60] Michel, K.N., Bertin, M.K., Deddy, K.T., Elie, K.N.U., Jack, K.B., Yvette, Y.M., et al. (2016) Risk Factors for Mortality of Newborn at Kolwezi Hospital. Open Access Library Journal, 3, e2849. https://doi.org/10.4236/oalib.1102849 